University of Nebraska - Lincoln

DigitalCommons@University of Nebraska - Lincoln

Faculty Publications: Department of Teaching, Department of Teaching, Learning and Teacher Learning and Teacher Education

Education

2009

\title{
A Sociocultural Perspective on ESOL Teachers' Linguistic Knowledge for Teaching
}

Jenelle Reeves

University of Nebraska-Lincoln, jreeves2@unl.edu

Follow this and additional works at: https://digitalcommons.unl.edu/teachlearnfacpub

Part of the Teacher Education and Professional Development Commons

Reeves, Jenelle, "A Sociocultural Perspective on ESOL Teachers' Linguistic Knowledge for Teaching" (2009). Faculty Publications: Department of Teaching, Learning and Teacher Education. 114.

https://digitalcommons.unl.edu/teachlearnfacpub/114

This Article is brought to you for free and open access by the Department of Teaching, Learning and Teacher Education at DigitalCommons@University of Nebraska - Lincoln. It has been accepted for inclusion in Faculty Publications: Department of Teaching, Learning and Teacher Education by an authorized administrator of DigitalCommons@University of Nebraska - Lincoln. 
Published in Linguistics and Education (2009) 20: 109-125. Copyright 2009, Elsevier. Used by permission. DOI: 10.1016/j.linged.2008.11.001

\title{
A Sociocultural Perspective on ESOL Teachers' Linguistic Knowledge for Teaching
}

\author{
Jenelle Reeves, University of Nebraska-Lincoln, Lincoln, Nebraska, United States, jreeves2@unl.edu
}

\begin{abstract}
Within a sociocultural frame, teacher knowledge finds its origin in the entirety of teachers' lived experiences, not just those experiences within teacher preparation. Teachers' biographies, including their experiences as language learners, shape their knowledge base for teaching English to speakers of other languages (ESOL). This study interrogates one element of that knowledge base: teachers' linguistic knowledge for teaching. Cases studies of two early career ESOL teachers with similar language learner biographies, that of first language (L1) Center English speakers with limited second language (L2) learning experienee, provided insight into the ways participants' language biographies informed their linguistic knowledge for teaching. Findings indicated that participants' L1 knowledge of English did not provide them with the linguistic knowledge they needed for ESOL teaching. Implications for ESOL teacher education include better attuning teacher preparation programs to teacher candidates' biographies.
\end{abstract}

Keywords: Sociocultural theory; Linguistic knowledge; Teacher learning; Teacher knowledge; ESOL teacher education

The questions of what constitutes linguistic knowledge for ESOL (English to speakers of other languages) teaching has engendered much interest recently as the field of teaching ESOL (TESOL) takes a sociocultural turn (Firth \& Wagner, 1997; Freeman \& Johnson, 1998, 2004, 2005; Johnson, 2006; Lantolf \& Johnson, 2007). Within a sociocultural frame, second language (L2) teacher knowledge, linguistic and otherwise, is understood as "normative and lifelong, as emerging out of and through experiences in social contexts: as learners in classrooms and schools, as participants in professional teacher education programs, and later as teachers in the settings where they work" (Johnson, 2006, p. 239). Teachers' learning and teaching experiences (in and out of language classrooms), are presumed to shape their knowledge base for L2 teaching, and this places new importance on the role of teachers' biographies in their development as ESOL teachers. This inquiry picks up the questions of how teachers' biographies, in particular their experiences as language learners, inform their linguistic knowledge for ESOL teaching.

The Knowledge Base for ESOL Teaching

Teachers teach from a knowledge base developed through their educational experiences as language learners and teachers, as well as their experiences as students, teachers, and members of various communities outside the realm of language education (Freeman, 2002; Johnson, 2006; Johnston \& Goettsch, 2000). As teachers' biographies differ, so too does their knowledge base. Even teachers with similar teaching and learning experiences will differ in the ways they take up, interpret, and internalize shared experiences (Lantolf \& Johnson, 2007). Despite this heterogeneity in ESOL teachers' knowledge base, as well as the heterogeneity of the innumerable settings for ESOL instruction and diversity of the English-learning student populations, ESOL teachers have in common the task of L2 teaching. The purpose of studying teachers' knowledge base is, in part, to tease out that which may be generalizable from teacher to teacher. Yet, it is also to interrogate the unique ways particular teachers know and come to know about language and L2 teaching in order to better understand how a teacher's biography may shape his knowledge base for ESOL teaching.

Socioculturally, ESOL teachers' knowledge base cannot be characterized as a monolithic cache of knowledge about language (KAL) or about pedagogy or both, each of which is separatedfrom theotherand from otherknowledgedomains (Dogancay-Aktuna, 2006; Freeman, 2002; Freeman \& Johnson, 1998; Johnson, 2006; Johnston \& Goettsch, 2000). Rather, teachers' knowledge for teaching, including their understandings of language, L2 teaching and L2 learning, is richly and complexly intertwined with other knowledge dimensions including, for example, their knowledge of teaching and learning in other subject areas. The study of teachers' knowledge for teaching, then, is no simple task. Yet to understand what teachers know and how they come to know it is fundamental to the work not only of ESOL teacher educators, but also ESOL teachers themselves.

The purpose of this study is to examine one element of teachers' knowledge base: linguistic knowledge for teaching. Interrogating what teachers know about language and L2 teaching and how they come to know what they know is complex 
work that is unlikely to yield statistical significance or straightforward generalizability. A comprehensive examination of the nature and composition of the linguistic knowledge of even one ESOL teachers would be a monumental task. This inquiry is a step towards articulating a comprehensive understanding of teachers' linguistic knowledge for teaching and its place within teachers' knowledge base for ESOL teaching. The inquiry is undertaken cautiously as a means of interrogating the influence and import of teachers' language learner biographies rather than as a means of determining the "best" biography for ESOL teaching effectiveness.

Lantolf and Johnson (2007) observed that "L2 teachers typically enter the profession with largely unarticulated, yet deeply ingrained, everyday concepts about language, language learning, and language teaching that are based on their own L2 instructional histories and lived experiences" (p. 884). This sociocultural shift and the subsequent forefronting of teachers' biographies in the development of the ESOL teaching knowledge base challenge the premise of transmission models of L2 teacher education. Namely, the shift undercuts a presumption that teachers develop their knowledge base for ESOL teaching mainly or even solely within the parameters of their teacher preparation programs.

The present inquiry explores two early career, L1 English speaking ESOL teachers' linguistic knowledge for teaching within the V.S. K-12 context and includes a detailed explication of three elements of their linguistic knowledge for teaching: knowledge about language, understanding of L2 learning processes, and critical language awareness. The three elements do not represent a comprehensive list of all that comprises teachers' linguistic knowledge for teaching; other elements no doubt exist and also deserve research attention. The three areas under study have been identified in previous research as highly relevant to linguistic knowledge for teaching, and for that reason, are pursued here.

'Teachers' linguistic knowledge for teaching cannot (and should not) be entirely separated from other domains of knowledge within a teacher's knowledge base. While taking a narrowed focus on these three elements of teachers' linguistic knowledge for teaching allowed for in-depth exploration of that knowledge, it also necessarily isolated that knowledge, compartmentalizing it in ways that may be inconsistent with the interrelated nature of teacher knowledge. Therefore, attention is drawn, whenever possible, to the relational nature of teachers' linguistic knowledge for teaching and the intersubjectivity of the domains of teachers' knowledge base.

\section{Linguistic Knowledge for ESOL Teaching}

Effective teachers need subject matter competence; they need to know how to solve the problems they pose to students and to know that there are multiple approaches to solving many problems. But such competence is not enough. Making the right choices as a teacher depends on knowing what kinds of errors or mistakes students are likely to make, being able to identify such mistakes when they occur, and being prepared to address the sources of the students' error in ways that will result in student learning. (Grossman \& Schoenfeld, 2005, p. 205).

Grossman and Schoenfeld (2005) echo the work of Shulman (1987) and others from a quarter century ago whose work expanded conceptualizations of teachers' knowledge base beyond subject matter competence to include such things as knowledge of pedagogy, learners, educational context, and content outside the primary subject of study. No longer was subject matter knowledge viewed as sole and sufficient teaching knowledge; effective representation of that subject matter to students was recognized as equally important (Freeman, 2002; Freeman \& Graves, 2004). Shulman (1987) coined the phrase pedagogical content knowledge (PCK) to describe the expanded conceptualization of teaching knowledge and observed that "[i]n order for a representation to be effective, teachers need to understand what makes a particular topic easy or difficult for students, what their preconceptions and misconceptions are, and what strategies are effective in dealing with their misconceptions" (pp. 49-50). Within the field of TESOL, PCK or subject matter representation (Freeman \& Graves, 2004) helped solidify the view that the effective, well-prepared ESOL teacher possessed not only deep linguistic knowledge of English but also an understanding of pedagogy, the learner, their educational context and how to arrange instruction in light of all those factors. Linguistic knowledge for teaching, then, includes not only such knowledge domains as a language's structure, social theories of language, and knowledge of the L2 learning process, it also includes teachers' schema for representing linguistic knowledge to learners in comprehensible, learnable ways.

As conceptualizations of teachers' knowledge base for teaching evolved, so, too, did understandings of how that knowledge base was built (Borg, 2003, 2005; Freeman, 2002; Freeman \& Johnson, ]998; Johnson, 2006; Johnston \& Goettsch, 2000; Tsui, 2003). Inquiry into how ESOL teachers develop linguistic knowledge for teaching has so far centered upon (1) teachers' experience and study of general (not only language but all subject matter) teaching and learning (Freeman \& Johnson, 1998); (2) teachers' experience and study of teaching ESOL (Borg, 1999; Cullen, 2002; Johnson, 2006; Johnston \& Goetsch, 2000; Mullock, 2006; Pennington, 2002); (3) teachers' experience and study of English as an L1 (Andrews, 2003a, 2003b; Bigelow \& Ranney, 2005; Borg, 1999; Johnston \& Goettsch, 2000; Murray, 2002; Popko, 2005); (4) teachers’ 
experience and study of English as an L2 (Jeannot, 2004; Matsuda, 2003; Park, 2006; see also Braine, 1999); and (5) teachers' experience and study of L2s other than English (Osborn, 2006; Reagan \& Osborn, 2005; Wright, 2002). Presumably, teachers' experience and study of L1s other than English would also be influential in shaping teachers' linguistic knowledge for ESOL teaching, but a search for such literature yielded no reports. The scholarship in the development of teachers' linguistic knowledge for teaching, then, falls into two general categories: development stemming from teachers' experiences as teachers (ESOL and otherwise) and development stemming from teachers' experiences as language learners (English and other languages). It is primarily teachers' experiences as learners and their related development of linguistic knowledge for teaching that are interrogated in this report.

ESOL Teachers' Experiences as Learners of English

How ESOL teachers leam English is significant to their understandings of the language. In Vygotskian terms, L1 and early childhood learners of English develop an everyday "spontaneous" understanding of the language (Lantolf \& Johnson, 2007).

Spontaneous concepts are formed during the concrete practical experiences of children as they are socialized into a culture. These concepts are largely invisible to conscious inspection. When someone attempts to bring this type of knowledge into consciousness the result is usually a vague, incoherent, incomplete, and even inaccurate statement of the concept. (p. 880)

Therefore, "if we ask a native English speaker why a particular sentence is ungrammatical, a typical response might be "Because it sounds wrong," or "I just wouldn't say it that way" (p. 880). An L1 speaker of English will likely identify the utterance "I enjoy to hike" (a common L2 learner confusion of which verbs do and do not take the infinitive) as a comprehensible yet problematic construction, but they may not be able to explain why it sounds wrong. L1 English speakers may well develop a deeper understanding of English (e.g. through academic study of the language), but they do not, by the default of their native speaker status, necessarily possess a depth of conscious linguistic knowledge that includes the ability to articulate that knowledge for ESOL teaching. Neither can it be said that L2 learners of English necessarily hold insight into infinitive-taking verbs, a point taken up in the next section.

L1 speakers of English typically develop a degree of everyday "nonspontaneous" understanding of English through the academic study of the language that takes place throughout their schooling years (Lantolf \& Johnson, 2007). Nonspontaneous concepts, such as the so-called rules of one's first language, "are usually intentionally taught and consciously acquired" (p. 880). The distinction between everyday spontaneous and nonspontaneous language maps onto an often-observed bifurcation of linguistic knowledge within the field of TESOL: teachers' knowledge of language (procedural knowledge) and their knowledge about language (declarative knowledge) (Andrews, 2003b; Johnson \& Goettsch, 2000). Knowledge of language is teachers' proficiency in the target language, including, for example, L1 ESOL teachers' everyday spontaneous knowledge as described above. KAL is teachers' analytical awareness and structural understanding of English. KAL would include, for example, knowledge of the forms and functions of tenses. At the same time, spontaneous and nonspontaneous knowledge are not unrelated. For example, L1 English speakers' close observation and inquiry of their own spontaneous knowledge of the language may lead to the deduction of language rules and norms.

Recent scholarship has expanded the conceptualization of KAL beyond the structural knowledge of a language to include teachers' beliefs, attitudes, and personal theories about the language (Andrews \& McNeill, 2005; Bigelow \& Ranney, 2005; Borg, 2005; Johnston \& Goettsch, 2000; Larsen-Freeman, 2004; Popko, 2005). Johnston and Goettsch (2000) included pedagogical knowledge for teaching the language as a necessary extension of KAL, noting that neither procedural nor declarative knowledge are entirely descriptive of the knowledge teachers utilize while teaching.

[t] he conscious awareness of grammar structures is as much apart of the teacher's knowledge base as the ability to use them in practice. The latter is a characteristic of all native speakers, and, as most ESL/EFL professionals would agree, being a native speaker does not in itself make one a good teacher. ..[i]t is also the case that knowledge of content does not translate automatically into pedagogical content knowledge -that the teacher knowing the rules is one thing, while what she does with that knowledge ('telling' it to the students or finding other ways to work with it) is something else. (p. 446)

Firth and Wagner $(1997,1998)$, also, observed that conceptualizations of linguistic knowledge in the field of L2 studies suffer from an overly mentalistic characterization of language as a fixed code of intricate rules, which are often accompanied by a long list of exceptions and caveats. Lantolf and Johnson (2007), following Firth and Wagner (1997, 1998), called for the reunification of language learning and meaning-making, one that "reorients the focus of language instruction to fea- 
ture centrally how meaning is situated in concrete human activity rather than in the language itself" (p.877). Fram this [Vygotskian] perspective, the activity of teaching and learning language is not focused on language as a stable, rule-governed linguistic system that must be acquired before people can engage in communication. Instead, it is concerned with enhancing language learners' communicative resources which are formed and reformed in the very activity in which they are used — concrete linguistically mediated social and intellectual activity (Lantolf \& Johnson, 2007, p. 878)

Socioculturally, then, teachers' linguistic knowledge for teaching has been recast with the learner and meaningmaking at the fore. Linguistic knowledge for teaching has become more than grammatical knowledge, or even the ability to teach linguistic structures well. Linguistic knowledge for teaching in the new sociocultural frame is teachers' ability to use and teach language in ways that grant learners a full range of expression. Language, in other words, is taught in service to the learner rather than the learner in service to the language-learning task. Such a re-conceptualization does not dismiss teachers' knowledge of the rules and codes of language as unimportant, rather it highlights the primacy of learners' meaning-making within the target language.

Having the resources to make meaning in multiple, unpredictable situations requires a conceptual understanding of language that allows learners to employ language strategically, in pursuit of their own purposes. Lantolf and Johnson (2007), drawing on Vygotsky's work, identify this knowledge as scientific.

[S]cientific concepts are systematic, coherent, and generalizable. From an educational perspective, therefore, scientific concepts have considerable developmental value because they liberate learners from the constraints usually imposed by their everyday experiences and allow them to function appropriately in any concrete circumstances in which they find themselves. (Lantolf \& Johnson, 2007, p. 880)

A scientific understanding of language takes language to be dynamic and in flux. Such an understanding eschews language as static with clearly defined, unchanging rules (i.e. an everyday, nonspontaneous understanding of language).

Nonspontaneous concepts are similar to the grammatical rules-of-thumb typically encountered in language textbooks.... The problem with this instructional approach is that rules-of-thumb are not always complete, coherent, or accurate. They generally describe what is typical in a specific context rather than an abstract principle that prornotes a deep understanding of the concept allowing learners to use the language across an array of contexts. (p. 880)

As an example, the construction, 'I'm loving it" violates the nonspontaneous rule-of-thumb that stative verbs do not take the progressive. Yet, the phrase "I'm loving it" is the ubiquitous slogan of a major fast food chain in North America. A nonspontaneous, rule-of-thumb approach does not have the nuance to account for such changeability in language use. Nor does it prepare learners to employ progressive stative verb constructions for learners' own means. The implication of the nonspontaneous/scientific distinction in the nature of language is that ESOL teachers themselves need a scientific understanding of the language if they are to help learners fully develop their own English language resources.

The scientific conceptual knowledge of English that Lantolf and Johnson (2007) describe, that which is "systematic, coherent, and generalizable" (p. 880), cannot be taken-for-granted in either L1 or L2 English speakers, as this knowledge seems to result from "theoretical investigation" undertaken with the intent of "selecting the essential characteristics of objects or events of a certain class and presenting these characteristics in the form of symbolic and graphic models" (Karapov, 2003 as quoted in Lantolf \& Johnson, 2007, p. 880). Such knowledge of English could be acquired by L1 and L2 English speakers through, for example, academic study of language but generally would not develop through everyday language use. L1 English speakers, then, do not necessarily, by default of their native English speaker status, come to the task of ESOL teaching with comprehensive, scientific linguistic knowledge for teaching.

ESOL Teachers' Experiences as Learners of Second Languages Other than English

From a, perhaps, commonsense viewpoint, monolingual ESOL teachers appear not to require L2 experiences since they are tasked with teaching their first language, in which they are, presumably, highly proficient. However, there are at least three challenges to this argument. First, L1 English speakers' knowledge about English is, as discussed above, informed by how (and at what age) they learned English, and the naturalized notion of L1 English teachers' superior linguistic knowledge for teaching does not hold (Canagarajah, 1999; Firth \& Wagner, 1997, 1998; Lantolf \& Johnson, 2007; Valdes, 1999; see also Ramanathan, 2002).

Second, while L1 English speakers with no or limited L2 learning experiences have leamed English as an L1, they do not have extensive firsthand experience of the process of L2 learning. From a sociocultural perspective, such teachers lack a primary source of linguistic knowledge for teaching: teachers' own experiences as L2 learners, which may include, for example, insight into how language can be effectively presented to learners. Borg (2003), in a review of teacher cognition in language teaching research, found linkage between language teachers' personal experiences as L2 learners and their subse- 
quent teachers' knowledge. “[T]eachers' prior language learning experiences establish cognitions about learning and language learning which form the basis of their initial conceptualisations of L2 teaching during teachereducation, and which may continue to be influential throughout their professional lives” (p. 88). Similarly, Gandara and Maxwell-Jolly (2006) observed that L2 learning experience provided teachers "a better understanding of the challenges and complexities of learning a second language, as well as the ways in which primary language can be used as a bridge to English" (p. 108).

Finally, Osbom (2006) observed that L2 learning not only provides teachers with firsthand experience of the technical and affective processes of L2 acquisition, it can also be understood as a social justice imperative.

[T] he fact that words embody concepts and culture in a way that does not always include a one-to-one correspondence with words in other languages is a lesson leamed only in the study of a second language. If the worldviews of residents of our global village are embodied, at least in part, in their languages, then the study of foreign languages is central to an education program among people committed to democracy. (p. 9)

L1 English speaking ESOL teachers without second language experiences embody the linguistic hegemony of English because, as speakers of a dominant language, they do not need other languages for communication. Speakers of non-dominant languages must, instead, learn English. L1 English speakers' L2 learning experiences may be one avenue for opening a window onto linguistic hierarchies that may otherwise be invisible to them.

It is important to note that a lack of experience with L2 learning may not necessarily lead teachers to incomplete or faulty conceptualizations of L2 learning processes and incomplete linguistic knowledge for teaching. It could also be the case that L2 teachers with extensive language learning experiences also have problematic or incomplete conceptualizations of the L2 learning process. Nonetheless, a promising avenue for developing linguistic knowledge for teaching is closed to L2 teachers with no or limited L2 learning.

ESOL Teachers' Linguistic Identities as Center/Periphery English Speakers

Native English speaker status is imbued with the unequal power relations between languages and nation states (Canagarajah, 1999; Fairclough, 1989; Pennycook, 1998, 2001; Phillipson, 1988, 1992; Valdes, 1999). The L1 English speaking ESOL teacher, exploiting (knowingly or not) the hegemony of English, has the unearned linguistic privilege of not needing to learn a second language as English, through a colonial past, has become the most widely spoken second language in the world.

Canagarajah (1999) observed that the terms native and nonnative English speaker are insufficient for capturing these sociopolitical nuances or the diversity of English speakers. Rather, the terms Center and Periphery better convey the power dynamics undergirding teachers' linguistic identity in relation to English. A Center English speaker is of a nation or community that "claims ownership over [standard] English" (p. 78). Center nations/communities "sustain their ideological land linguistic] hegemony by keeping less-developed communities in Periphery status" (p. 78). Periphery speakers of English are "historically recent users" (p. 78) of English or users of non-dominant varieties of English (e.g. Black vernacular English). Periphery English speakers can be found both outside and inside Center nations.

'Teachers' linguistic knowledge for teaching is infused not only with their experiences learning English and L2s other than English, but also with their linguistic identity as Center/Periphery speakers of English. The nature of the L1 Center speaking teachers' linguistic identity, depending on their social contexts, may be such that their own linguistic privilege may be virtually invisible to them, yet it may be starkly visible to English learners and periphery English speaking teachers.

\section{The Study}

Examining teacher knowledge requires an inquiry approach that captures the complex, situated nature of teaching. Bringing teachers' mentallives (Freeman, 2002) to the fore in educational necessitates research strategies that provide thick description (Geertz, 1973) of teachers, teaching, and context such as case study, ethnography, or narrative inquiry. The present study utilizes case study method to provide in-depth description of the linguistic knowledge for teaching of the two participants, Sean and Rita, ${ }^{1}$ who were L1 Center English-speaking novice ESOL teachers with limited L2 learning experience. Hawkes and Olson (as quoted in Freeman, 2002) explain the descriptive (versus prescriptive) task in the study of teaching. "Looking from a teacher-thinking perspective at teaching and learning, one is not so much striving for the disclosure of the effective teacher, but for the explanation and understanding of teaching processes as they are" (p. 5). The case study methodology, although utilizing small sampie sizes, has the advantage of focusing on depth and detail in description in ways large-sample studies cannot. Cases focus on "understanding the dynamics present within single settings" (Eisenhardt, 2002, p. 8), and thoughtfully chosen cases can serve as prototypical subjects that can embody the global in the local (Lincoln \& Guba, 2002).

${ }^{1}$ Although data on three participants were gathered, this report is limited to discuss of two participants. All names are pseudonyms. 
The 18 months of the study saw Sean and Rita complete an ELL certification program at a state university in the V.S., including their program-ending student teaching experience. Each participant took at least one course taught by the researcher, and the researcher's and participants' acquaintance spanned two years in Rita's case and 18 months in Sean's. The bulk of data collection occurred during participants' student teaching semester in which each taught 50-min ESOL classes five days a week for 16 weeks: in Rita's case, two classes per day and in Sean's, one class per day. Additional data collection (primarily interview data) occurred before and continued beyond student teaching.

Participants student taught in two middle schools in a school district of 33,000 K-12 students in a Midwestern city of approximately 250,000 people: Sean in a level 4 (advanced intermediate) classroom at a school with 6.6\% ELLs; Rita in level 1 (beginning) and level 2 (advanced beginning) classrooms at a school with 17\% ELLs. The city in which the participants attended university and completed their student teaching was a refugee resettlement area with a highly linguistically diverse K-12 ELL population of 43 home languages other than English, primarily Spanish, Arabic, Vietnamese, and Nuer.

Throughout the study Sean and Rita sat for a number of long audiotaped interviews, each lasting between 30 and 80 min. In Sean's case, two formal interviews were conducted in student teaching and one post-program. In Rita's case four long interviews were conducted in her student teaching semester and two post-program. The initial interview was semi-structured using the attached interview guide as a framework (Appendix A), and subsequent interviews centered on discussions of participants' language learner biographies and the observations made by the researcher in each participant's classroom. Additionally, numerous informal interviews and e-mails were exchanged between participants and the researcher throughout the study. During the researchers' visits to participants' classrooms, the action and dialogue of the class were scripted with particular attention given to participants' explicit language instruction including, for example, presentation and discussion of grammatical points. For analysis, field notes and interviews were transcribed by the researcher and pooled with other data sources, including e-mail messages and course documents from participants' university classes and ELL classrooms.

As the purpose of the study was to investigate teachers' linguistic knowledge for teaching, data were searched for instance in which participants' linguistic knowledge was on display. Instructional episodes in which participants instructed grammar explicitly and/or addressed learners' errors provided rich sources of data on participants' knowledge and beliefs about language, as well as their conceptualization of effective L2 pedagogy.

Data were analyzed iteratively as they were gathered, transcribed, read, and reread in order to identify patterns in Sean's and Rita's linguistic knowledge for teaching. From these patterns preliminary findings were developed and shared with participants whose comments then became an additional data source. Preliminary findings were continually open to revision in light of supporting and contradicting data. Findings represent saturation, the predictable repetition of evidence coming from multiple data sources. In consideration of Lincoln and Guba's (2002) advice to "rhetorically exemplify the interpersonal involvement" (p. 214) of researcher, participant, and reader in case reports, findings are presented as two contextualized cases that bring together participants' biographies, a representative classroom episode, researcher observations, and participants' own narration of their thinking about language and ESOL teaching.

\section{Sean}

Despite two years of Spanish study in high school, Sean considered himself monolingual. To Sean being a successful language learner meant being able to use his L2 to communicate, and he felt his study of Spanish did not result in such success. "Aside from very basic conversation, however, I can not use Spanish or any other foreign language" (course document, January 23, 2006). According to Sean's recounting of his experience as a Spanish student in high school, the limited L2 instruction he received focused on the acquisition of error-free vocabulary and grammar, and student learning was demonstrated through pencil and paper tests. Sean's limited L2 learning experience did not present language as an authentic tool of communication by situating it, for example, within a particular languaculture (Lantolf \& Johnson, 2007). Rather, language and linguistic knowledge were presented as a fixed system of rules, in line with a nonspontaneous, rule-of-thumb conception of language. Sean observed that he left his L2 coursework with neither the ability to recall much of what he had learned nor the ability to communicate in Spanish, an ability that would have served him well in his current part-time job at a grocery store.

Perhaps as a result of the [traditional] teaching style, or because I was unmotivated to learn the language (I saw no use for it outside of school), I retain very little workable Spanish knowledge to this day... Today, as a college student working at a grocery store, I have a few opportunities for speaking Spanish on a somewhat-regular basis. I know Spanish words for numbers and can count back change in the language. I know a few basic words for foods and can communicate, albeit awkwardly, with a Spanish speaker who has a question about the location of a particular item. (course document, January 23,2006$)$ 
Interestingly, despite his insistence that he was a failed L2 learner, Sean did communicate ("albeit awkwardly") in Spanish with Spanish-speaking patrons at his part-time job in the grocery store. He understood and answered customers' queries about price and location of items. Sean, however, conceptualized successfullanguage acquisition as a learner's ability to communicate in a non-"awkward" manner, and therefore he continued to perceive himself to be an unsuccessful language learner.

When Sean entered university, he applied his high school Spanish credits to the foreign language requirement of his undergraduate program, which, at the same time, satisfied the foreign language requirement that accompanied his post baccalaureate program in middle level and ELL certification. He had no other significant experiences as an L2 learner/user until his contact with the Spanish speakers at his part-time job in a grocery store, as described above.

During the course of the study Sean was seeking a middle level (grades 4 through 8) teaching certificate with specializations in the areas of social sciences and language arts, and he decided to add an ELL endorsement to his middle level license, pursuing both endorsements concurrently. He decided to pursue ELL certification after one of his middle level professors encouraged him. Sean's first experiences with mainstreamed ELLs in a middle schools social studies classroom were positive, which, along with his perception that the additional endorsement would increase his marketability, solidified his decision to add the ELL endorsement.

Sean and Rita completed a 21-credit hour add-on ELL endorsement program at a state university in the Midwest. The program, based on their state's Department of Education's requirements for ELL certification, was similar to ESOL certification programs throughout the nation (Christopher, 2005). In typical ESOL teacher education programs in the V.S., criteria for certification are developed and monitored at the state level. State criteria are commonly informed by accreditation organizations such as the National Council on the Accreditation of Teacher Education (NCATE). In the case of Sean and Rita program, the seven state-Ievel certification criteria were addressed in seven three-credit hour courses: content area reading, cross-cultural communications, linguistics for the classroom teacher, second language acquisition, ESOL methods, ESOL assessment, and ESOL student teaching. Although this course-bycourse approach is common in teacher preparation programs, Johnston and Goettsch (2000) note that the cumulative effect of course-by-course coverage can be the inadvertent separation of teaching knowledge into discrete categories, where the interconnected nature of teaching knowledge is de-emphasized.

Sean and Rita were required to take one course in linguistics for the ELL endorsement. Each took a different section of the course, taught by different instructors. Therefore, their experiences were not entirely comparable. However, all sections of the course were designed to be an introduction to linguistics for classroom teachers in general, not only ELL teachers. A perspective on English linguistics for L2 English learners was not consistently offered in either Sean's or Rita's section of the course.

In Sean's ELL classroom

The formal curriculum in Sean's ELL classroom revolved around language arts, a content area of interest to both Sean and his mentor teacher, and literature, speech, and writing activities were common in the class. Sean's approach to teaching grammar was to look for patterns in learners' errors in their work and speech and to prepare mini-Iessons to remediate the errors. Sean reported that he was not particularly enthusiastic about grammatical study, and that he found it a bit "dull." He suspected the students did as well. However, he viewed the occasional mini-Iesson in explicit grammar instruction to be necessary for students to build their ability to identify errors in their English. He believed that if learners continued making the same errors over and over again without correction, the errors could fossilize and become impervious to correction.

At the time of the classroom episode below, Sean was in his thirteenth (of sixteen) week of student teaching in a Level 4 (advanced intermediate) ELL classroom. The class was eight students of six language backgrounds including Spanish, Nuer, Arabic, and Vkrainian. The lesson, following Sean's typical class format, began with a grammatically focused warmup, in this case single and plural present tense, third person verbs (e.g. he drives, they drive).

Sean: Students, we have a warm-up just like we do almost everyday.

Sean holds up a copy of the worksheet that students have before them. The worksheet has a dozen sentences on it with one blank in each sentence. A verb is provided in parentheses at the end of each sentence, and students are to write the correct conjugation of the verb in the blank. One of the items reads "Diane is a wonderful storyteller. She to tell stories. (like)"

Sean: These are action words, verb tenses. They tell us something that's happening right now, has happened, or will happen. Sean's explanation of verb tenses is cursory, as this is information he has presented to students before. Together Sean and students do numbers 1 and 2 with Sean reading the item and asking for student volunteers to provide the answers. The two items require students to use the third person "s" on the singular verbs "tell" and "go." After completing the first two items successfully with the class, Sean directs students to 
finish the worksheet on their own, and the students work in silence for a few minutes.

Sean: Read the sentences and ask yourself in your mind if it makes sense, if it sounds right.

Students continue to work silently on the worksheet, and after afew more minutes Sean and the class begin to check their answers with Sean calling on students to give their answers for each item. Sean offers the following explanation of the present tense after he and the students have checked a few answers, some of which students have answered incorrectly.

Sean: These are all present tense because Diane is telling stories now, so she likes telling stories.

Sean over enunciates the s on "likes," and continues checking answers, correcting students' errors, which are numerous. Sean acknowledges to the students that this grammatical feature is difficult.

Sean: Rules for tense are confusing because the rules aren't always the same. If she says, 'I remember,' but here it says 'she remembers,' it's one of those things where the more you read, the more you catch on and things just sound right. Okay, they perform or they performs?

Sean asks the students to raise their hands to vote for one or the other. About half of the students choose performs and the other half choose perform.

Sean: Perform. Why?

Malina (calling out): It just sounds wrong.

Sean: I go with Malina, it just sounds wrong, but if you grew up not speaking English, you might need to study these rules. (field notes, December 8, 2006, pp. 1-2)

As the example above indicates, Sean's approach to grammar instruction was to create grammar mini-lessons focused on learners' observed errors, "we need to be Strunk and White every once in a while; we need to fine-tune specific things" (interview, January 29, 2007, p. 3). In the classroom excerpt above, Sean drew learners' attention to a common error, the omission of the third person s on present tense verbs. By being "Strunk and White," Sean and his students studied the grammatical rules-of-thumb presented by known English language authorities, even though Sean acknowledged that the rules of English were not always consistent. In an interview after the classroom episode above, Sean explained his understanding of the rule-of-thumb for third person present tense verb construction.

Researcher: So, how did you explain the third person, do you remember? Why we have to put s?

Sean: Um, I just said any, if you're referring to any single person aside from yourself, it has to end with s, any verb has to end with s. And I just explained the rule in a couple different ways and had extended practice. I practiced with the whole group and practiced on their own. Um, I didn't know any other way to say it other than that. Any single person except for yourself, you have to add the s. (interview, December 8, 2006, p. 4)

The rules-of-thumb Sean offered his students were, as in the excerpt above, at times incomplete and potentially problematic. Sean'streatment of the present tense, for example, did not include a distinction between verbs of enduring states (e.g. "like") in the "Diane likes telling stories" item and verbs of habitual action (e.g. "they perform"). He intimated that the present progressive and the simple present had the same function (to express an action happening now), which is an incomplete, if not misleading, explanation. Sean's explanations of grammar in cases such as this suggested that his own knowledge of English grammar was largely spontaneous. Therefore, when he presented grammatical rulesof-thumb, Sean often demonstrated a limited understanding of the rule and became confused by language evidence he offered students, which at times, contradicted and/or confused rather than supported the rule under study.

In addition to providing students with grammar rules in order to avoid errors, Sean urged his students to pay attention to what "sound[ed] right."

[A]s a native English speaker myself, I have this, as Noam Chomsky explains it, I have this ability to understand grammatical rules without knowing the grammatical rules. So, I had to teach myself, what is the rule here? I know that "he walk" is wrong, but why? What's the rule behind it? What's the rule that I know intrinsically without ever learning it? So, it really pushed me to, um, sit down and figure out how I was going to articulate this. And that's all of, you know, what teaching really iso I think, it's not only ELL but content area knowledge that, um, once I learned it in a book and now it's just, um, apart of my regular thinking cycle that I don't really think about metacognitively how I learned it. So I have to [ask myself], 'how did I learn it? How might they learn it and break it down? So, it has to be real basic to an extent ifyou're not L1. Um, 'cause to especially to, uh, Asian students, Asian-American students, "he walk to the store" sounds fine. (interview, January 29, 2007, p. 3).

Sean believed that his knowledge of English came "without ever learning it," and he struggled to make sense of how 
ESOL learners could learn and internalize the language, so that they, too, could identify what sounded right. He hypothesized that learners' study of grammar rules and language practice would develop their ability to identify right and wrong language.

\section{Rita}

Rita, a second career ELL teacher, worked in business for 15 years and raised a family before returning to college in her 40s to pursue her teaching certificate in 2004. Rita was inspired to become an ELL teacher, in part, by reading Mary Pipher's book The Middle of Everywhere: The World's Refugees Come to Our Town (2002), which details the resettlement of political and economic refugees to the U.S. state of Nebraska.

Growing up in the Midwest in the 1960s and 1970s, Rita had little opportunity to learn a second language in or out of school. Her language learning experiences included a teaser French course is junior high school (lasting less than a semester) that was designed to entice students to emoll in French in high school, which Rita did not. She had little recollection of her experience in the course, recalling only that she was required to memorize and perform short dialogues. Rita's second and final L2 learning experience was a six-week course in German conversation that she took in preparation for her European honeymoon. This course required memorization of phrases that would likely prove helpful to American tourists in German-speaking Austria. On her honeymoon, however, she and her husband found little need to use their memorized German phrases as most Austrians they interacted with spoke some English.

Rita regretted having limited opportunities to learn another language. While she felt that her monolingualism was a disadvantage in ESOL teaching, she also felt it was not a disqualifier for becoming a good ELL teacher. "I think ELL teachers who speak more than one language may be more effective because they understand, firsthand, what their students are going through. But, I think understanding other cultures is equally important. And, for me, that is a more realistic goal" (Rita, course document, 2005, p. 3). Like Sean, Rita completed the 21 hour ELL certification program, and she pursued certification in business education (a grades 7-12 endorsement area) concurrently with her ELL (K-12) endorsement. Prior to student teaching, Rita had no formal teaching experience, although, as a parent, she had occasionally assisted teachers in her children's elementary school classrooms.

\section{In Rita's ELL Classroom}

Rita student taught in a level 2 (advanced beginning) middle school ELL classroom that enrolled between 6 and 12 students throughout the semester (the fluctuation was due to students changing levels, as well as the arrival of one new student). Five native and multiple second languages other than English were spoken by Rita's students who came from eight nations including Korea, Sudan, Mexico, and Congo. The following classroom episode was a mini-lesson on adjectives that took place in the last few minutes of a lesson in Rita's seventh week of student teaching. Earlier in the period, the class finished reading the book Borreguita and the Coyote by Aardema (1991), and the mini-lesson began with Rita's nomination of a new topic: adjectives. By this time in her student teaching, Rita planned and executed lessons independent of her mentor teacher.

Rita: What I want to talk about now is adjectives. What are they?

Rita pauses, waiting for student volunteers, but no one answers.

Rita: Give me an adjective to describe this room. Shilo?

Shilo shakes her head no, and Rita nods, accepting Shilo's preference not to answer. Waiting for other student responses, Rita walks from the front and center of the room to a whiteboard at the front and right.

Rita: I want to talk about the characters in the book.

Rita writes "Coyote" and "Lamb" on the white board.

Rita: How would you describe them?

Rita points to George who has his hand raised.

George: Has long teeth.

Rita pauses, seeming to search for a word.

Rita: Toothy?

Rita writes "tootby" on the whiteboard under "Coyote."

Shilo (calling out): Believes wrong thing.

Again, Rita pauses as if she is searching for a word.

Rita: Here's a word that describes that: gullible. Heard of that?

Rita writes "gullible" on the whiteboard under "Coyote." No one responds to Rita's question, but Mike offers a new description of the coyote.

Mike: Like [sic] to eat sheep. 
Rita: He does.

Rita shows some exasperation that the students are not giving her the answers she expected, which apparently are one-word adjectives. She puts her finger to her temple and looks up to the ceiling quizzically to show the students that she is thinking about how to reword Mike's answer.

Rita: I'm trying to think of a word. Sheep-loving?

Rita writes "sheep-loving" on the board.

Rita: What I want you to do is think of Lamb and write as many adjectives as you can to describe the lamb. Students are silent and unmoving, seemingly unsure of the task. Rita has assigned them. Before either students or teacher address the task, the bell rings, and the students pack up and headfor the door. (field notes, March 6, 2006, pp. 4-5)

Rita struggled in this lesson to get students to understand that an adjective was a one-word descriptor. Student responses to Rita's request for "a word that describes" the coyote indicated that while her students understood the notion of describing, they did not have a clear understanding of the adjectival form Rita was seeking, one-word descriptors. Rita was perplexed by her students' multi-word responses because she anticipated one-word answers. In response to the students' flawed answer, she reformulated the multi-word descriptions by suggesting both "toothy" as substitute for "has long teeth" and "sheep-loving" for "like to eat sheep." Rita employed word-generation skills in these reformulations (e.g. adding -y to a noun or -ing to a verb to create an adjective). However, she either failed to recognize that her word-generation skills were not shared by her students, or she was unable to articulate these word-generation techniques to her students.

Like Sean, Rita took a rule-of-thumb approach to grammar instruction, and her knowledge of English rulesof-thumb was, at times, insufficient for the teaching task. Interestingly, Rita's students provided accurate, largely error-free, creative descriptions of the characters (e.g. 'believes wrong thing'), thereby using language to communicate a meaningful, comprehensible message. Although Rita did not overtly correct learners' multi-word descriptions, she reformulated them into oneword adjectives, indicating to students that their answers were, in some way, flawed.

Rita identified this episode as typical of a dilemma she faced throughout her student teaching, the dilemma of "at what point and how to teach specific grammar rules" (Rita, interview, June 1, 2006, p. 2). She observed that the students didn't seem to "get" adjectives in this lesson, and she had similar difficulty instructing other linguistic structures.

The real technical, diagramming each part of the-I don't know how to do that. Am I doing them [ELLs] a disservice if I don't know how to do it, or if we don't do it? I do it [grammar instruction] out of defense because I'm so much more interested in doing the other part of it that I wouldn't probably be the one to do the real technical part. (interview, June 1, 2006, p. 4)

Rita perceived her understanding of English grammar to be non-"technical," and she generally avoided grammatical instruction and explanation in her teaching, relating her students' English-learning experience to her L1 English speaking children's experience. Rita observed that her own children had not needed grammar instruction to learn English, and she wondered if attention to grammar in the ELL classroom was unnecessary. At the same time, Rita was compelled to address grammar on occasion out of a sense of duty. Rita got the sense from her teacher education program that grammatical instruction was part of L2 teaching, and that it was her duty to provide it.

\section{Discussion}

Teachers' language learner biographies interacted with their linguistic knowledge for teaching in at least three ways in this study: their knowledge about English, their knowledge about L2 learning, and their critical language awareness. Each is discussed at length below.

Teacher Biography and Knowledge about English

As Lantolf and Johnson (2007) predicted of L1 English speakers, Sean and Rita evidenced an everyday spontaneous understanding of English that was "largely invisible to conscious inspection" (p. 880). Sean noted that the third person $\mathbf{s}$ just "sounded right” in present tense verbs, and Rita generated one-word adjectives from learners' multiword descriptions without being able to articulate how she did so. As Lantolf and Johnson (2007) also predicted of L1 speakers' articulation of English rules, the teachers' explanations were "not always complete, coherent, or accurate” (p. 880). In Sean's case, he made no distinction between the simple present and the present progressive by identifying both as action "happening now." Rita insisted that descriptions be offered in one-word adjectives and reformulated students' multi-word descriptions into one-word adjectives without explanation of adjectival construction or the relationship between adjectival clauses and one-word adjectives (e.g. that both describe).

Sean and Rita possessed a largely spontaneous understanding of English, each employed a rule-of-thumb approach to 
grammar teaching that relied on conscious, nonspontaneous knowledge of English of which neither had a complete grasp, and each subsequently experienced moments of dissonance in their ESOL teaching. The cases of Sean and Rita demonstrate that being L1 speakers of English did not provide them with the knowledge about language that they needed for ESOL teaching. In fact, Sean and Rita's knowledge of English (their 'everyday' understanding as Center speakers) in concert with their limited knowledge about English lead to frequent confusion.

Neither participant taught from or for a scientific knowledge of English that could "liberate learners from the constraints usually imposed by their everyday experiences and allow them to function appropriately in any concrete circumstances in which they find themselves" (Lantolf \& Johnson, 2007, p. 880). Rita's impulse to teach for meaning (by eliciting and using students' language in her lesson about adjectives) was a promising turn, but it was stymied by her rule-bound approach to adjectives in which she co-opted and corrected student language that was already meaningful. Sean's observation that the language rules he taught were inconsistent and, at times, unhelpful was not enough for him to look again at his rule-ofthumb approach to language instruction.

\section{'Teachers' Biography and Knowledge about L2 Learning}

"Much of teaching effectively depends on understanding student thinking — or better yet, anticipating and preparing for student understanding ahead of time.” (Grossman \& Schoenfeld, 2005, p. 227)

Having little or no experience with L2 acquisition appears to have impacted Sean's and Rita's linguistic knowledge for teaching in at least two ways: their ability to predict learner difficulties with the language and their understanding of the L2 learning processes of learners. Sean was surprised by the continual recurrence of third person s errors in his students' language, and Rita was similarly bewildered by her students' multi-word responses when she expected oneword answers. On the whole Sean and Rita did not anticipate learner difficulties well, and they were often blindsided by unanticipated learner errors that they were hard-pressed to explain. Subsequently, both experienced episodes of instructional paralysis as they grappled with how to proceed with instruction in the face of unexpected and inexplicable learner errors.

Both participants also lacked a comprehensive experiential frame of reference for understanding the processes of second language acquisition from a learner's perspective. Rita, who had extremely limited L2 learning experience, reported relying on her observation of her children's L1 acquisition of English to help make sense of ELLs' English acquisition. Sean, although he studied Spanish for two years, made little conscious connection between his own language learning and his work as an ELL teacher. If Sean's limited L2 learning experience had had much to tell him about L2 language teaching and learning, the insight might best be described as how not to teach and how not to learn a second language. According to Sean's self-report of his study of Spanish, the experience was not "participant-relevant" (Firth \& Wagner, 1997, p. 285) or "interactionally attuned" (p. 296) to Sean as a Spanish speaker, and language was presented as an inert rule-bound object of study. The experience left him with a view of himself as a defective communicator (Firth \&: Wagner, 1997), and he adopted a deficit view of himself as a Spanish speaker by focusing on what he could not do (communicate fluidly and freely) rather than on what he could do (communicate awkwardly).

Sean and Rita each studied second language acquisition theory as part of their ELL teacher preparation coursework, yet little evidence of their knowledge of L2 acquisition theory presented itself in the study, beyond Sean's mention of Noam Chomsky. Perhaps the course was poorly taught or its curriculum impoverished. But, it is also possible that lacking an experiential frame of reference in L2 learning-as well as L2 teaching, as the course was taken prior to their student teaching experiences-the participants' meaningful engagement with L2 acquisition theory was inhibited.

Teacher Biography and Critical Language Awareness

During the course of the study, neither Sean nor Rita evidenced a critical awareness of linguistics-based power dynamics at play in the teaching and learning of ESOL in their educational contexts. Sean and Rita did not question, for example, their own linguistic identities (as L1 Center speakers of standard V.S. English with little L2 experience) in relation to their task as ELL teacher or in relation to their students' linguistic identity (L2 Periphery English learners in English-medium V.S. classrooms). Neither problematized the ease with which they were inducted into the field of ESOL teaching, nor did they interrogate their own qualifications for the TESOL profession. Sean added the ELL endorsement to enhance his marketability as a teacher. Rita pursed ELL endorsement to be of service to newcomers that she saw as needy and under-served. Both, seemingly unwittingly, used their linguistic identity as currency to enter and front the ELL classroom in ways that were apparently unchallenged by their teacher preparation programs, school sites, or learners, and their linguistic privilege was invisible to them. 
Implications for ESOL Teacher Education

The limitations in Sean and Rita's linguistic knowledge for teaching suggest an obvious solution: more and better coursework in linguistics, L2 learning, and critical language awareness. However, such a solution for strengthening the linguistic knowledge for teaching of novice, L1 Center English speaking ESOL teachers who have limited L2 learning is, at best, incomplete. A comprehensive solution lies in holistically attuning ESOL teacher preparation with teacher biographies and the ways teachers learn.

The presumption that additional coursework will yield deeper linguistic knowledge for teaching is not well-supported in research, particularly when teachers' exposure to linguistic knowledge occurs without contextualization for the L2 language classroom (Andrews, 2003a, 2006; Andrews \&: McNeill, 2005; Bigelow \&: Ranney, 2005; Borg, 2003; Brumfit, 1991; Freeman, 2002; Grossman et al., 2005; Murray, 2002; Popko, 2005; Wright, 2002). Similarly, it is doubtful that requiring more L2 (or foreign language) credit hours before or during ESOL teacher preparation will necessarily expand teacher candidates' linguistic knowledge for L2 teaching unless that L2 learning could be overtly connected to the L2 teaching task by the ESOL teacher candidates. Simply requiring more coursework in linguistics and foreign language in ESOL teacher preparation programs such as the one Sean and Rita completed is not what is needed. "What is needed is not less, and also not more, but something different,” Johnston \&: Goettsch (2000, p. 462) observed in their study of veteran ESOL teachers' knowledge base. That something different is biographically responsive ESOL teacher preparation.

Teacher learning, as studies of teaching expertise commonly assert, is a process that begins before teacher candidates enter and continues long after they complete their teacher preparation programs (Freeman \&: Johnson, 1998; Hammerness, Darling-Hammond, \&: Bransford, 2005; Johnson, 1996; Tsui, 2003). In terms of teaching expertise, early career teachers like Sean and Rita are novices with little experience and expertise as teachers. Sean and Rita can even be viewed as quite illprepared for the task of ESOL teaching, particularly in comparison to descriptions of what expert ESOL teachers know and do.

ESL teachers must be skilled at gathering linguistic information from their students to choose suitable linguistic structures to teach and to assess students' linguistic development. They have to be able to predict what language will be problematic in a text or class activity and then decide how to address the language in the lesson. (Bigelow \&: Ranney, 2005, p. 179)

Sean and Rita, during the time of this study, fall dramatically short of this description of the expert ESOL teacher. They do not possess a comprehensive knowledge about English or the ability to anticipate learner difficulties. Subsequently Sean and Rita are not particularly efficient or innovative in the classroom, two hallmarks of teaching expertise (Hammerness et al., 2005; Tsui, 2003).

Although the language teaching expertise of Sean and Rita was clearly limited when viewed prescriptively, their potential for developing teaching expertise is apparent when viewing their cases descriptively. In these two cases, Sean and Rita entered the field of teaching ESOL with a knowledge base shaped by particular experiences (and not others, such as L2 learning). Looking closely at their cases, suggestions of their nascent L2 teaching expertise and burgeoning knowledge base are evident. Sean, for example, attempts to put theory (Chomskian language acquisition theory) into practice, thereby practicalizing theoretical knowledge (Tsui, 2003). "What's the rule that I know intrinsically without ever learning it? So, it really pushed me to, um, sit down and figure out how I was going to articulate this" (Sean, interview, January 29, 2007, p. 3). Such practicalizing is, as Tsui (2003) observed, indicative of developing L2 teaching expertise. Sean exhibited a tendency toward reflective practice, questioning his knowledge of English and how he might render that knowledge learnable for his students.

Rita similarly evidenced the beginning of second language teaching expertise through her close attention to learners' decoding and comprehension of English text.

[D] uring the assessments I noticed that they could decode words, I assumed that they knew what they [the words] meant when they could say it. I didn't think about them saying them and not having any idea what they meant. And that's in the section when students just said the words and I thought, "wow, it's amazing," the words that they were saying And then we went to reading comprehension, and, oh, I was just shocked that it was an entirely different thing the decoding and comprehension, how different they are. (Rita, interview, February 7, 2006, p. 2)

Although she had neither a scientific understanding of English nor an experiential knowledge of L2 learning, Rita was observant of her learners and their English-learning experiences. She recognized her own misconception about decoding and reading comprehension and revised her understanding of how students learn to read. Such close attention to students' learning is key for Rita to eventually anticipate learners' difficulties and prepare relevant instruction. 
Despite the shortcomings already discussed, L1 Center English speakers who have little more than an everyday understanding of English do bring particular assets to the study of English for ESOL teaching, and biographically responsive teacher preparation would acknowledge and build on those assets. These teachers, as Sean and Rita demonstrated, are able to use their insiders' knowledge of English in the context to identify errors easily and possibly offer learners alternative ways of expressing utterances. In asense, teachers like Sean and Rita need assistance in reverse engineering their own English proficiency, wherein L1 Center speakers interrogate their own English proficiency and decipher ways of rendering their L1 learnable to L2 English students. Towards that end, additional coursework in linguistics and L2 learning may serve teachers well, but that coursework ought to build from teacher candidates' biographies as language learners and be embedded within their current (or future) task of ESOL teaching for it to be particularly meaningful.

In teacher learning, there is no straightforward connection between what teachers know about their subject matter and their effectiveness in teaching it (Freeman \& Johnson, 1998). Within the field of TESOL, for example, much work remains to be done in delineating how L1 English teachers' develop linguistic knowledge for teaching English as a second language. This study adds supporting evidence to the observation that teachers' linguistic knowledge is not the same as teachers' linguistic knowledge for teaching.

$[\mathrm{K}]$ nowledge that informs activity is not just abstracted from theory, codified in textbooks, and constructed through principled ways of examining phenomena, but also emerges out of a dialogic and transformative process of reconsidering and reorganizing lived experiences through the theoretical constructs and discourses that are publicly recognized and valued within the communities of practice that hold power.”(Johnson, 2006, p. 240-241).

Linguistic knowledge for ESOL teaching is, as Johnson, argues, socially mediated and context-bound. Building teachers' linguistic knowledge for teaching, then, calls for an orchestrated effort in which teacher candidates carefully observe their own and their students' language learning, interrogate their knowledge of language within their practice of teaching ESOL, and participate in communities of practice that offer teacher candidates sites for accessing and sharing expertise.

As part of this orchestration, ESOL teacher education programs that are sensitive to candidates' biographies advocate a comprehensive teacher induction process. Sean and Rita encountered gaps in their linguistic knowledge for ESOL teaching during student teaching, and during this time they began to critically interrogate their own understandings of English. Yet there was little recognition from the teacher preparation program or the school site that Sean and Rita were questioning their own linguistic knowledge while teaching ESOL. Such on-the-job inquiry into their subject matter ought to be anticipated by teacher preparation programs and schools, recognized as legitimate, and supported through extended induction activities such as mentorship programs or teacher learning communities in which teacher education programs and school sites work in tandem. Meanwhile, the complement to extended induction of ESOL teacher candidates is meaningful coursework and field experiences early in teacher preparation programs. With purposeful attention to teachers' particular biographies as learners and teachers, ESOL teacher preparation programs could foster and promote teacher learning so that teachers exiting credentialing programs will have developed an emerging L2 teaching expertise including a robust linguistic knowledge and are poised to continue that development post-program.

Teacher learning in and out of formal teacher preparation programs should be nurtured and shaped toward the development of teacher praxis (Johnson, 2006; Pennycook, 2001). Praxis, teachers' theorized practice, is not developed simply through the academic study of linguistics, L2 learning theory and/or L2 pedagogical technique. Nor is it necessarily developed through the practice of teaching. It is developed through all of these and engagement with discourses and communities of practice within and outside the school site. "This [teacher learning] will occur only when teachers have multiple opportunities to connect their ways of knowing to theory, both emic and etic, through modes of engagement that lead to praxis, and more importantly, when they are deeply embedded in communities of practice that seek to ask these more substantive questions" (Johnson, 2006, p. 242). In order for teachers to develop a robust linguistic knowledge of English for teaching, an understanding of the L2 processes their students are undergoing, and a recognition of their linguistic identity in relation to their learners, teacher learning (both pre-professional and on-the-job) ought to be anticipated as ongoing, context-embedded, and, to varying degrees, social. Comprehensive, biographically responsive teacher education programs build teaching praxis.

Finally, theroie of teacher education programs is not simply to transfer ESOL teacher candidates to school sites where candidates will then, in the school site context, develop situated teaching expertise and a robust praxis in the natural course of day-to-day teaching. School sites may not, as in the cases of Sean's and Rita's schools, articulated is courses that challenge the status quo of English hegemony, including local preferences for L1 Center speaking English teachers (rather than, for example, L2 Periphery English-speaking teachers) and English-only schooling policies. Teacher preparation programs may be teachers' only community of practice in which a discourse of critical language awareness challenging the lin- 
guistic status quo is taken up. ESOL teacher education, then, may play a singular role in heightening teachers' meta-awareness in which teachers adopt "a self-reflexive and self-critical attitude that encourages reflection and analysis on the practices of a community including those related to...one's own individual participation in their creation and sustenance" (Ramanathan, 2002, p. 202). Osborn (2006) similarly advocates macrocontextualization in L2 teacher preparation. Macrocontextualization references the "local, regional, national, and global in which the programs are situated," (p. 10) in which "social, political, historical, and ethical considerations" comprise the context for language teaching and learning.

Conclusion

In order to recognize teachers' ways of knowing as legitimate knowledge, L2 teacher education must accept the multiple forms that their ways of knowing and their ways of coming to know may take. (Johnson, 2006, p. 242)

Teachers' biographies as language learners shape their linguistic knowledge for ESOL teaching, as we saw in the cases of Sean and Rita. ESOL teacher candidates enter the profession with widely divergent experiences as language learners and teachers, and ESOL teacher education cannot (and should not attempt to) control for or replace those experiences. What teacher education can do is become biographically responsive by acknowledging what and how teachers know in relation to ESOL teaching and learning. Teachers like Sean and Rita bring particular assets as well as particular limitations for their development of linguistic knowledge for teaching and ESOL teaching expertise. To serve teachers well, teacher preparation programs ought to build teaching and learning experiences around those assets and limitations. The field of TESOL has long recognized that a one-size-fits-all language program is inappropriate for the vast heterogeneity of the English learners we teach. We must also admit the same is tme of one-size-fits-all ESOL teacher preparation programs.

Appendix A. Interview guide

1. Tell me about your decision to seek ELL certification

a. What area are you gaining initial certification in?

b. What grade level and subject area(s) do you hope to teach?

2. Tell me about your experience as a language learner.

a. What languages have you studied? How long did you study?

b. How easy/difficult did you find language study?

c. Describe your proficiency in each language.

3. Tell me about your experience teaching English as a second language.

a. Describe any challenges you have faced.

b. How confident are you as a teacher of ELLs?

4. How do you decide what to teach in your ELL classes?

a. Do you use a curriculum guide, a set of standards or a particular text?

b. How do you handle students' language errors?

5. What have found to be unexpected and/or surprising about teaching ESOL so far?

6. Do you have any other comments on your journey to becoming an ESL teacher?

\section{References}

Aardema, V. (1991). Borreguita and the Coyote. New York: Alfred A. Knopf.

Andrews, S. (2003a). 'Just like instant noodles': L2 teachers and their beliefs about grammar pedagogy. Teachers and Teaching: Theory and Practice 9: 351-375. Andrews, S. (2003b). Teacher language awareness and the professional knowledge base of the L2 teacher. Language Awareness 12: 81-95.

Andrews, S. (2006). The evolution of teachers' language awareness. Language Awareness 15: 1-19. Andrews, S., \& A. McNeill (2005). Knowledge about language and the 'good language teacher.' In: N. Bartels (Ed.), Applied Linguistics and Language Teacher Education (pp. 159-178). New York: Springer.

Bigelow, M.H., \& S.E. Ranney (2005). Pre-service ESL teachers' knowledge about language and its transfer to lesson plan- 
ning. In: N. Bartels (Ed.), Applied Linguistics and Language Teacher Education (pp. 179-200). New York: Springer.

Borg, S. (1999). Teachers' theories in grammar teaching. ELT Journal 53: 157-167.

Borg, S. (2003). Teacher cognition in language teaching: a review of research on what language teachers think, know, believe, and do. Language Teacher 36: 81-109.

Borg, S. (2005). Experience, knowledge about language and classroom practice in teaching grammar. In: N. Bartels (Ed.), Applied Linguistics and Language Teacher Education (pp. 325-340). New York: Springer.

Braine, G. (1999). Non-Native Educators in English Language Teaching. Mahwah, N.J.: Lawrence Erlbaum.

Brumfit, C. (1991). Language awareness in teacher education. In: C. James \& P. Garrett (Eds.), Language Awareness in the Classroom (pp. 24-39). New York: Longman.

Canagarajah, A.S. (1999). Interrogating the "native speaker fallacy": Non-linguistic roots, non-pedagogical results. In: G. Braine (Ed.), Non-Native Educators in English Language Teaching (pp. 77-92). Mahwah, N.J.: Lawrence Erlbaum.

Cullen, R. (2002). The use of lesson transcripts for developing teachers' classroom language. In: H. Trappes-Lomax \& G. Ferguson (Eds.), Language in Language Teacher Education (pp. 219-236). Philadelphia, Pa.: John Benjamins.

Dogancay-Aktuna, S. (2006). Expanding the socio-cultural knowledge base of TESOL teacher education. Language, Culture, and Curriculum 19: 278-295.

Eisenhardt, K.M. (2002). Building theories from case study research. In: A.M. Huberman \& M.B. Miles (Eds.), The Qualitative Researcher's Companion (pp. 5-36). Thousand Oaks, Calif.: Sage.

Fairclough, N. (1989). Language and Power. London: Longman.

Firth, A., \& J. Wagner (1997). On discourse, communication, and (some) fundamental concepts in SLA research. The Modern Language Journal 81: 285-300.

Firth, A., \& J. Wagner (1998). SLA property: no trespassing! The Modern Language Journal 82: 91-94.

Freeman, D. (2002). The hidden side of the work: teacher knowledge and learning to teach. Language Teacher 35: 1-13.

Freeman, D., \& K. Graves (2004). Examining language teachers' teaching knowledge. In: M. Hawkins \& S. Irujo (Eds.), Collaborative Conversations among Language Teacher Educations (pp. 87-104). Alexandria, Va.: TESOL.

Freeman, D., \& K.E. Johnson (1998). Reconceptualizing the knowledge-base of language teacher education. TESOL Quarterly 32: 397-417.

Freeman, D., \& K.E. Johnson (2004). Common misconceptions about the "quiet revolution": a response to Yates and Muchisky. TESOL Quarterly 38: 119-127.

Freeman, D., \& K.E. Johnson (2005). Response to Tarrone and Allwright. In: D. J. Tedick (Ed.), Second Language Teacher Education: International Perspectives (pp. 25-32). Mahwah, N.J.: Lawrence Erlbaum.

Gandara, P., \& J. Maxwell-Jolly (2006). Critical issues in developing the teacher corps far English learners. In: K. Tellez \& H.C. Waxman (Eds.), Preparing Quality Educators for English Language Learners: Research, Policies, and Practices (pp. 99-120). Mahwah, N.J.: Lawrence Erlbaum.

Geertz, C. (1973). The Interpretation of Cultures: Selected Essays. New York: Basic Books.

Grossman, P., \& A. Schoenfeld, with C. Lee (2005). Teaching subject matter. In: L. Darling-Hammond \& J. Bransford (Eds.), Preparing Teachers for a Changing World: What Teachers Should Learn and Be Able to Do (pp. 201-231). San Francisco: Jossey-Bass.

Hammerness, K., L. Darling-Hammond \& J. Bransford, with D. Berliner, M. Cochran-Smith, M. McDonald \& K. Zeichner (2005). How teachers learn and develop. In: L. Darling-Hammond \& J. Bransford (Eds.), Preparing Teachers for a Changing World: What Teachers Should Learn and Be Able to Do (pp. 358-389). San Francisco: Jossey-Bass.

Jeannot, M. (2004). Investigating missed opportunities and cultural displays: a reader reacts to Anne Lazaraton's 'Incidental displays of cultural knowledge in the nonnative-English-speaking teacher's classroom.' TESOL Quarterly 38: 325-330.

Johnson, K.E. (2006). The sociocultural turn and its challenges for second language teacher education. TESOL Quarterly 40: 235-257.

Johnston, B., \& K. Goettsch (2000). In search of the knowledge base of language teaching: explanations by experienced teachers. CanadianModern Language Review 56: 437-468.

Lantolf, J.P., \& K.E. Johnson (2007). Extending Firth and Wagner's (1997) ontological perspective to L2 classroom praxis and teacher education. The Modern Language Journal 91: 877-892.

Larsen-Freeman, D. (2004). The nature of linguistics in a language teacher education program. In: M. Hawkins \& S. Imjo (Eds.), Collaborative Conversations among Language Teacher Educations (pp. 69-86). Alexandria, Va.: TESOL.

Lincoln, Y.S., \& E.G. Guba (2002). Judging the quality of case study reports. In: A.M. Huberman \& M.B. Miles (Eds.), The Qualitative Researcher's Companion (pp. 205-215). Thousand Oaks, Calif.: Sage.

Matsuda, P.K. (2003). Proud to be a nonnative English speaker. TESOL Matters 13(4): 15.

Mullock, B. (2006). The pedagogical knowledge base of four TESOL teachers. The Modern Language Journal 90: 48-66. 
Murray, H. (2002). Developing language awareness and errar detection: What can we expect of novice trainees? In: H. Trappes-Lomax \& G. Ferguson (Eds.), Language in Language Teacher Education (pp. 187-198). Philadelphia, Pa.: John Benjamins.

Osborn, T.A. (2006). Teaching World Languages for Social Justice: A Sourcebook of Principles and Practices. Mahwah, N.J.: Lawrence Erlbaum.

Park, Y. (2006). Will non-native-English-speaking teachers ever get a fair chance? Essential Teacher 3: 32-34.

Pennington, M.C. (2002). Examining classroom discourse frames: An approach to raising language teachers' awareness of and planning for language use. In: H. Trappes-Lomax \& G. Ferguson (Eds.), Language in Language Teacher Education (pp. 149-172). Philadelphia, Pa.: John Benjamins.

Pennycook, A. (1998). English and the Discourse of Colonialism. New York: Routledge.

Pennycook, A. (2001). Critical Applied Linguistics: A Critical Introduction. Mahwah, N.J.: Lawrence Erlbaum.

Phillipson, R. (1988). Linguicism: structures and ideologies in linguistic imperialism. In: T. Skutnabb-Kangas \& J. Cummins (Eds.), Minority Education: From Shame to Struggle (pp. 339-358). Clevedon, U.K.: Multilingual Matters.

Phillipson, R. (1992). Linguistic Imperialism. Oxford: Oxford University Press.

Popko, A.J. (2005). How MA-TESOL students use knowledge about language in teaching ESL classes. In: N. Bartels (Ed.), Applied Linguistics and Language Teacher Education (pp. 387-404). New York: Springer.

Ramanathan, V. (2002). Enhancing the critical edge in L2 teacher-education: some issues in advanced literacy. In: M. Schleppegrell \& C. Colombi (Eds.), Developing Advanced Literacy: Meaning with Power (pp. 187-207). Mahwah, N.J.: Lawrence Erlbaum Associates.

Reagan, T.G., \& T.A. Osborn (2005). The Foreign Language Educator in Society: Toward a Critical Pedagogy. Mahwah, N.J.: Lawrence Erlbaum.

Shulman, L. (1987). Knowledge and teaching: foundations of the new reform. Harvard Educational Review 57: 1-22.

Tsui, A.B.M. (2003). Understanding Expertise in Teaching: Case Studies of ESL Teachers. Cambridge, U.K.: Cambridge University Press.

Valdes, G. (1999). Non-native English speakers: language bigotry in English mainstream classrooms. ADFL Bulletin 31: 43-48.

Wright, T. (2002). Doing language awareness: Issues far language study in language teacher education. In: H. Trappes-Lomax \& G. Ferguson (Eds.), Language in Language Teacher Education (pp. 113-130). Philadelphia, Pa.: John Benjamins. 
